\title{
LIST OF PRINCIPAL PERSONS \\ IN THE BOOK
}

(alphabetical by surname)

Pauline вosibori: Wife of Musa Nyandusi; mother of Simeon Nyachae Joseph IvITA: Cofounder of Catholic church in Kilungu Location, Machakos District; grandfather of Martha Ngina Mule

Ruth katuku: Wife of Philip Mule; mother of Harris Mule

Jackson KAMAU: Chairman of the KTDA and business associate of Charles Karanja

Charles Kibe Karanja: General manager of the KTDA during the 1970s; son of Karanja wa Kiarii and Njeri (Nyagitiri) Karanja

Njeri (Nyagitiri) KARANJA: Mother of Charles Karanja

Philomena Ndanga Karanja: Wife of Charles Karanja

KARANJA wa Kiarii: Prosperous farmer in Kiambu District; father of Charles Karanja

Geoffrey KARIITHI: Head of the civil service under President Kenyatta in the 1970s

Jomo KENYATTA: First president of Kenya

KIARII wa Wanjema: Grandfather of Charles Karanja

Mwai KIBAKI: Minister of finance under President Kenyatta; vicepresident under President Moi

Mbiyu KoInange: Minister of state in the Office of the President and confidant of Kenyatta

Dan мвоGo: Assistant director of livestock development in charge of artificial insemination; brother of Ishmael Muriithi

Tom мвоуа: Trade unionist and leader in independence struggle; early secretary general of KANU; key cabinet minister under Kenyatta; assassinated in 1969 
Daniel arap Mor: Second president of Kenya

Harris MULE: Chief economist and deputy permanent secretary for planning under President Kenyatta; permanent secretary for the Ministry of Finance under President Moi; son of Philip Mule and Ruth Katuku

Martha Ngina MULE: Wife of Harris Mule; granddaughter of Joseph Ivita

Philip MULE: Former president of the African Tribunal Court for Southern Machakos District; father of Harris Mule

Ishmael MURIITHI: Director of veterinary services under Presidents Kenyatta and Moi; son of Elijah Waicanguru and Lydia Wangeci

Martha Wangui Munene MURIITHI: Wife of Ishmael Muriithi

Philip NDEGWa: Principal secretary to the Ministry of Finance under President Kenyatta; governor of the Central Bank under President Moi

Charles nJonjo: Attorney general under Presidents Kenyatta and Moi Druscilla Kerubo NyachaE: Second wife of Simeon Nyachae

Esther Nyaboke NYACHAE: First wife of Simeon Nyachae

Grace Wamuyu NYACHAE: Fifth wife of Simeon Nyachae

Martha Mwango NyachaE: Third wife of Simeon Nyachae; sister of Lawrence Sagini

Simeon NYACHAE: Provincial commissioner under President Kenyatta; chief secretary under President Moi; son of Musa Nyandusi and Pauline Bosibori

Sylvia NYACHAE: Fourth wife of Simeon Nyachae; sister of Jane Kiano, wife of Gikonyo Kiano, prominent Kikuyu cabinet minister throughout the Kenyatta years

Musa NYANdusi: Former senior chief of Nyaribari Location, Kisii District; father of Simeon Nyachae

Oginga ODINGA: Luo leader of independence struggle in Nyanza Province; first vice-president of Kenya; founder of KPU

Lawrence SAGINI: First member of Parliament from Kisii District; brother of Martha Mwango Nyachae

Elijah waicanguru: Former elder (judge) of the African Tribunal court for Tetu Division, Nyeri District; father of Ishmael Muriithi and Dan Mbogo

Lydia WANGECI: Wife of Elijah Waicanguru; mother of Ishmael Muriithi and Dan Mbogo 
